\title{
Risk factors for bovine mastitis with the isolation and identification of Streptococcus agalactiae from farms in and around Haramaya district, eastern Ethiopia
}

\author{
Biniam Tsegaye Lakew ${ }^{1,2} \cdot$ Taresa Fayera $^{1} \cdot$ Yimer Muktar Ali ${ }^{1}$
}

Received: 29 July 2018 / Accepted: 30 January 2019 / Published online: 11 February 2019

(C) The Author(s) 2019

\begin{abstract}
A cross-sectional study was carried out to determine the prevalence and risk factors of bovine mastitis caused by Streptococcus agalactiae from farms in and around Haramaya district, eastern Ethiopia. A total of 384 lactating cows were selected from small-, medium-, and large-scale production systems. California mastitis test (CMT) was used for screening subclinical mastitis. Out of the total animals examined, 63.02\% $(n=242)$ had mastitis, where 6.77\% $(n=26)$ and 56.25\% $(n=216)$ were clinical and subclinical mastitis respectively. The quarter-level prevalence was $29.04 \%(n=446)$, from which the clinical form was $6.38 \%$ $(n=98)$ and the subclinical was $22.66 \%(n=348)$, and the rest quarters were blind 3.32\% $(n=51)$. Milk samples from clinical as well as CMT positive quarters were cultured for isolation of $S$. agalactiae, where $10.3 \%(n=46)$ resulted in growth of the bacterium. The prevalence of mastitis was found to be statistically significant among the age groups $(p=0.002)$, breed $(p=$ $0.000)$, and parity $(p=0.000)$. Similar findings were found to the extrinsic risk factors considered; as production type $(p=0.010)$, teat injury $(p=0.02)$, and type of floor $(p=0.000)$. The study confirmed the importance of $S$. agalactiae as the cause of contagious mastitis and also identified the associated risk factors in the study farms and hence warrants serious attention.
\end{abstract}

Keywords CMT $\cdot$ Haramaya district $\cdot$ Risk factors $\cdot$ Streptococcus agalactiae

\section{Introduction}

Mastitis is the inflammation of the mammary gland that has over 130 different isolated causative agents from mastitis milk samples but Staphylococcus aureus, Streptococci, and members of the Enterobacteriaceae are among the most common etiological agents in cows and in other animal species (Quinn et al. 1999). It is often classified as subclinical or clinical depending on the severity of the disease or contagious and environmental based on the causative agents (Quinn et al. 2002; Andrews et al. 2003). Mastitis caused by Staphylococcal and streptococcal are the commonest and economically a great concern for dairy farming.

Biniam Tsegaye Lakew

bintse2@gmail.com; blakew@myune.edu.au

1 College of Veterinary Medicine, Haramaya University, P.O.Box 138, Dire Dawa, Ethiopia

2 School of Environmental and Rural Science, University of New England, Armidale 2351, Australia
Unlike Staphylococcus aureus, Streptococcus agalactiae is one of the mastitis-causing bacteria that can only grow and multiply in the udder (Andersen et al. 2003). However, it can survive for short time periods on hands, milking machine parts and teat skin, leading to its spread from cow to cow during milking. $S$. agalactiae is most commonly introduced into a clean herd when an infected cow is purchased. Because of the silent nature of infections and highly contagious nature, infections can spread quickly (Sandy 2011). As with most infectious diseases, mastitis risk factors depends upon three components; exposure to microbes, cow defense mechanisms, and environmental and management factors (Mungube et al. 2004).

Mastitis has been contributing to reduced milk production and a major source of economic loss to the dairy industry (Erskine 1992), through reduced milk yield and quality, cost of drugs and veterinary treatment, discarded milk, and forced culling (Quinn et al. 1999). Mungube et al. (2005) estimated the economic losses from urban and peri urban areas of Addis Ababa, to be US\$58 and 78.65 per cow and per lactation, respectively. In addition to its economic impact, Streptococcus agalactiae; group B Streptococcus (GBS), is 
the major etiologic agent of invasive neonatal infections in humans in industrialized countries, causing sepsis, pneumonia, meningitis, Osteomylits, and soft tissue infections (Baker 2000).

In Ethiopia, a few studies have been conducted with the purpose of estimating the prevalence of bovine mastitis (Kifle and Tadele 2008; Almaw et al. 2009; Sori et al. 2011; Dabash et al. 2014). However, mastitis as a disease particularly the subclinical mastitis has received very little attention. Therefore, the study was conducted with the objectives to determine the prevalence and associated risk factors of bovine mastitis caused by Streptococcus agalactiae from farms in and around Haramaya district, Ethiopia.

\section{Materials and methods}

\section{Study areas}

The study was conducted in selected small holder, mediumand large-scale dairy farms in and around Haramaya district, Ethiopia. It is located $503 \mathrm{~km}$ east of Addis Ababa; at 41 ${ }^{\circ} 59^{\prime}$ $58^{\prime \prime}$ latitude and $09^{\circ} 10^{\prime} 24^{\prime \prime}$ longitudes with $2000 \mathrm{~m}$ a.s.l. The district receives an average annual rain fall approximately $900 \mathrm{~mm}$, and climatically, there are two ecological zones of which $66.5 \%$ is midland and $33.5 \%$ is lowland (Shimelis 2010).

\section{Study population and husbandry practice}

Lactating Holstein-Zebu and local Zebu breeds from 20 dairy farms in and around Haramaya district were categorized into small-scale dairy production (SSDP), medium-scale dairy production (MSDP), and large-scale dairy production (LSDP) based on herd size having 5 or less, 6-30, and 72-171 dairy cattle, respectively (Mureda and Mekuria 2008). The cows in Haramaya University dairy farm were all cross breeds (Holstein Friesian $\times$ Zebu) and milked by a milking machine twice a day (morning and afternoon) in a separate milking parlor. The cows were managed under intensive husbandry practice in stall barn made of concrete floor. They were mainly fed hay, brans, and silage. Regular washing of milker's hand before and after milking of the cows is an established practice at the farm. Age of animals was determined from birth records and categorized as young adults (3-6 years), adults ( 6 to $\leq$ 10 years), and old ( $>10)$. Stage of lactation was categorized as early ( $1-4$ month), middle ( $>4-8$ month), and late ( $>8$ month to the beginning of dry period). Parity was categorized as few (with $\leq 3$ calves), moderate (4-7 calves), and many ( $>7$ calves) (Biffa et al. 2005). The barn floor was grouped into poor (barn which was not well managed and muddy) and good (barn floor which is concrete or well managed).

\section{Sample size determination}

The desired sample size for the study was calculated using the formula given by Thursfield (2005) with an expected prevalence rate of $50 \%, 95 \%$ confidence interval, and $5 \%$ absolute precision:

$\frac{n=1.96^{2 *} p_{\exp }\left(1-p_{\exp }\right)}{d^{2}}$

where

$n$ required sample size

$p_{\text {exp }} \quad$ expected prevalence

$d^{2} \quad$ desired absolute precision

So, a total of 384 lactating cows with about 1485 teat quarters were considered for the study.

\section{Study design and sampling strategy}

A cross-sectional study was conducted to determine the prevalence and associated risk factors of bovine mastitis caused by S. agalactiae. Cows were examined directly for clinical and indirectly using CMT for subclinical mastitis. Purposive sampling method was used to select study farms based on their willingness to be part of the study. The study animals were only lactating cows and were selected randomly.

\section{Study methodology}

\section{Structured questionnaire}

Structured questionnaires were developed to include information on cow attributes such as breed, age, parity number, lactation stage, teat or udder condition (lesion, fibrosis, atrophy), tick infestation of udder or teat, presence of blind teat, milk condition (watery, bloody, pussy). The age, lactation stage, and parity numbers were recorded from farm record documents, farm owners, and milkers. The farm attributes like herd size, production type, and status of barn floor were also considered in the questionnaire.

\section{Clinical inspection and preparation of udder and teat for sample collection}

First, udders and teats were physically examined by visualization and then palpation to detect if there is fibrosis, visible injury, tick infestation, atrophy of tissue, and any blindness. The udder and teats were disinfected with alcohol impregnated cotton, and washing is practiced when the udder is full of dung or dirty materials. The teat on the far side of the udder is 
Table 1 The prevalence of bovine mastitis at cow and quarter levels

\begin{tabular}{lllllll}
\hline & \multicolumn{2}{l}{ Cow level } & & & \multicolumn{2}{l}{ Quarter level } \\
& Positives & Prevalence (\%) & & No. of teats & Positives & Prevalence (\%) \\
\hline Blind & 51 & 13.28 & & 1536 & 51 & 3.32 \\
Clinical & 26 & 6.77 & & 1536 & 98 & 6.38 \\
Subclinical & 216 & 56.25 & & 1536 & 348 & 22.66 \\
Total & 242 & 63.02 & & 1536 & 446 & 29.04 \\
\hline
\end{tabular}

cleaned first than those on the near side. Scrubbing was continued until the towel remains clean (Moges et al. 2011).

\section{Milk sample collection and CMT}

The first two streams of milk were discarded and approximately $2-3 \mathrm{ml}$ of milk samples was collected into the mastitis paddle from individual quarters immediately after the udder is dry. Teats towards sample collection were taken first and then far once (Christos 2011). CMT was carried out on all sample collected in the mastitis paddle. The CMT reagent is mixed with the quarter milk sample that has been collected in the mastitis paddle in approximately equal proportion of the milk sample. Then, after the mixture was swirled in rotary motion, the result is then read within $10-15 \mathrm{~s}$ as negative, trace, $+1,+$ 2 , and +3 (Radostitis et al. 2007).

\section{Bacteriological isolation and characterization}

Approximately $10 \mathrm{ml}$ of milk from positive quarters collected into sterile test tubes was placed in ice box and transported to the Haramaya University, Veterinary Microbiology Laboratory. The milk samples were bacteriologically examined according to the procedures employed by Quinn et al. (1999). A loopful of milk sample was streaked on blood agar base enriched with $7 \%$ sterile sheep blood for each quarter. Blood agar plates were incubated aerobically at $37^{\circ} \mathrm{C}$ for 24 $48 \mathrm{~h}$. The plates were examined for gross colony morphology, Gram's stain, and hemolytic characteristics after 24-48 h. Presumptive colonies of Streptococcus species were selected

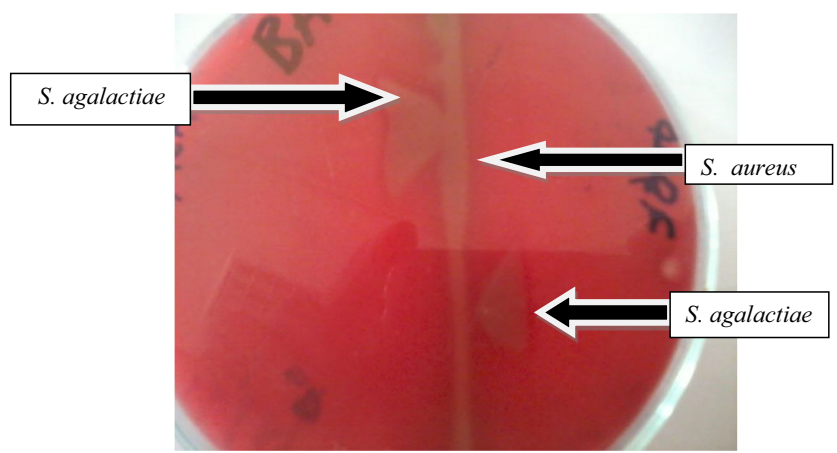

Fig. 1 The "arrow head" formation at the junction of Staphylococcus aureus and Streptococcus agalactiae and sub-cultured on nutrient agar and Edward media and incubated aerobically at $37^{\circ} \mathrm{C}$ for $24-48 \mathrm{~h}$. The catalase negative cocci were considered as Streptococci (Quinn 2002). The esculin negative colonies were preserved on nutrient agar plates for CAMP (Christie, Atkins, Munch-Petersen) test. $S$. agalactiae were identified by the hemolysis, not hydrolyzing esculin on Edward media and CAMP test.

\section{Data management and analysis}

The data generated during the sample collection and from the questionnaire were entered into the Microsoft Excel spread sheets and was later analyzed by using STATA version 11 software. The effect of risk factors with possible association of the disease was analyzed using chi-square. The associations between dependent and independent variables were tested, and $p<0.05$ was taken as statistically significant.

\section{Results}

\section{Overall prevalence}

Out of 384 lactating cows, $63.02 \%(n=242)$ were affected by mastitis and from the total of 1536 quarters examined, the prevalence to the quarter level was $29.04 \%(n=446)$ and the rest $3.32 \%(n=51)$ were blind. The prevalence of both clinical and subclinical at quarter and cow level is shown (Table 1).

\section{Isolation of Streptococcus agalactiae}

A total of 446 milk samples were collected and cultured from clinically and CMT-positive quarters; the prevalence of the S. agalactiae at the quarter level was found to be $10.3 \%$ (Fig. 1).

\section{Prevalence based on risk factors}

\section{Intrinsic risk factors}

The prevalence of mastitis at the cow level showed statistically significant difference $(p<0.05)$ among different parity numbers, breeds, and ages considered in the study (Table 2 ). 
Table 2 The prevalence of mastitis based on the intrinsic risk factors

\begin{tabular}{lrlccc}
\hline Intrinsic risk factors & Total animals examined & Positive animals $(\%)$ & prevalence & $\chi^{2}$ & $p$ value \\
\hline Breed & & & & & \\
Local & 74 & $29(39.2)$ & 7.55 & 23.3 & 0.000 \\
Crossbreed & 310 & $213(68.7)$ & 55.47 & & \\
Age & & & & & \\
Young adult & 96 & $50(52.1)$ & 13.02 & 17.3 & 0.002 \\
Adult & 137 & $78(56.9)$ & 20.31 & & \\
Old & 151 & $114(75.5)$ & 29.69 & & \\
Parity & & & & & \\
Few & 201 & $89(44.3)$ & 23.18 & & \\
Moderate & 65 & $40(61.5)$ & 10.42 & 88.1 & 0.000 \\
Many & 118 & $113(95.8)$ & 29.43 & & \\
lactation stage & & $135(65.5)$ & 35.16 & 6.2 & 0.185 \\
Early & 206 & $50(52.6)$ & 13.02 & & \\
Middle & 95 & $57(68.7)$ & 14.84 & & \\
Late & 83 & 242 & 63.02 & & \\
Total & 384 & & &
\end{tabular}

\section{Extrinsic risk factors}

Management factors such as production type, teat injury, and floor types were also evaluated where all of them had a statistically significant difference $(P<0.05)$ on the prevalence of mastitis (Table 3).

\section{Prevalence of bovine mastitis at farms level}

The study also revealed the prevalence of mastitis at the different farms (Table 4).

\section{Discussion}

The study showed that the prevalence of bovine mastitis from farms in and around Haramaya district to be $63.02 \%$ at cows' level as determined by the CMT and clinical examinations of the udder. This finding is in agreement with the report of $63.11 \%$ by Kassa et al. (2014) in Hawassa and Wando Genet and $61.11 \%$ by Tolla (1996) in South Wollo. However, the prevalence was higher than the report of $34.9 \%$ by Biffa et al. (2005), $40.40 \%$ by Dego and Tareke (2003), 52.9\% by G/Michael et al. (2013) in Southern Ethiopia, and $46.7 \%$ by Abera et al. (2013) in Adama town and $53.25 \%$; by Biniam et al. (2015) in Dire Dawa town but lower than the report of Mekibib et al. (2010a, b) in Holeta town in Central Ethiopia and Zeryehun et al. (2013) in and around Addis Ababa who reported 71.05 and $74.7 \%$ respectively. This variability in the prevalence between different reports could suggest the complexity of the disease, which involves the interaction of several factors mainly of farm management practices, production type and environment, animal risk factors, and causative agent; its prevalence is expected to vary from place to place (Radostitis et al. 2007).

The prevalence of clinical and subclinical mastitis were 6.77 and $56.25 \%$, respectively. The clinical prevalence in this study was comparable to the report of Bishi (1998) who reported the prevalence of $5.3 \%$ in Addis Ababa and lower than

Table 3 The prevalence of bovine mastitis based on the extrinsic risk factors

\begin{tabular}{|c|c|c|c|c|c|}
\hline $\begin{array}{l}\text { Extrinsic risk } \\
\text { factors }\end{array}$ & $\begin{array}{l}\text { Total } \\
\text { animals } \\
\text { examined }\end{array}$ & $\begin{array}{l}\text { Positive } \\
\text { animals } \\
(\%)\end{array}$ & prevalence & $x^{2}$ & $\begin{array}{l}p \\
\text { value }\end{array}$ \\
\hline \multicolumn{6}{|l|}{ Production types } \\
\hline Small scale & 39 & $18(46.2)$ & 4.69 & 13.4 & 0.010 \\
\hline Medium scale & 177 & $103(58.2)$ & 26.82 & & \\
\hline Large scale & 168 & $121(72.0)$ & 31.51 & & \\
\hline \multicolumn{6}{|l|}{ Teat injury } \\
\hline Present & 11 & $10(90.9)$ & 2.60 & 7.9 & 0.02 \\
\hline Absent & 373 & $232(62.2)$ & 60.42 & & \\
\hline \multicolumn{6}{|l|}{ Tick infestation } \\
\hline $\begin{array}{l}\text { Absent } \\
\text { (negligible) }\end{array}$ & 363 & $226(62.3)$ & 58.85 & 3.85 & 0.427 \\
\hline Moderate & 7 & $4(57.1)$ & 1.04 & & \\
\hline Infested & 14 & $12(85.7)$ & 3.13 & & \\
\hline \multicolumn{6}{|l|}{ Type of floor } \\
\hline Concrete & 306 & $209(68.3)$ & 54.43 & 18.58 & 0.000 \\
\hline Muddy & 78 & $33(42.3)$ & 8.59 & & \\
\hline \multicolumn{6}{|l|}{ Milking type } \\
\hline Manual & 328 & $201(61.3)$ & 52.34 & 3.6 & 0.165 \\
\hline Machine & 56 & $41(73.2)$ & 10.68 & & \\
\hline Total & 384 & 242 & 63.02 & & \\
\hline
\end{tabular}


Table 4 The prevalence of mastitis at farm level

\begin{tabular}{|c|c|c|c|c|c|c|}
\hline Farms & $\begin{array}{l}\text { Total animal } \\
\text { examined }\end{array}$ & $\begin{array}{l}\text { Clinical } \\
(\%)\end{array}$ & $\begin{array}{l}\text { Prevalence } \\
(\%)\end{array}$ & $\begin{array}{l}\text { Subclinical } \\
(\%)\end{array}$ & $\begin{array}{l}\text { Prevalence } \\
(\%)\end{array}$ & Total $(\%)$ \\
\hline 1 & 38 & $4(10.53)$ & 1.04 & $23(60.5)$ & 5.99 & $27(7.03)$ \\
\hline 2 & 14 & $3(21.43)$ & 0.78 & $7(50)$ & 1.82 & $10(2.6)$ \\
\hline 3 & 22 & $1(4.55)$ & 0.26 & $8(36.36)$ & 2.08 & $9(2.34)$ \\
\hline 4 & 5 & 0 & 0 & $4(80)$ & 1.04 & $4(1.04)$ \\
\hline 5 & 5 & $1(20)$ & 0.26 & $3(60)$ & 0.78 & $4(1.04)$ \\
\hline 6 & 23 & 0 & 0 & $13(56.5)$ & 3.39 & 13 (3.39) \\
\hline 7 & 3 & 0 & 0 & $2(66.7)$ & 0.52 & $2(0.52)$ \\
\hline 8 & 12 & $1(8.33)$ & 0.26 & $3(25)$ & 0.78 & $4(1.04)$ \\
\hline 9 & 3 & $1(33.33)$ & 0.26 & 0 & 0 & $1(0.26)$ \\
\hline 10 & 5 & $1(20)$ & 0.26 & 0 & 0 & $1(0.26)$ \\
\hline 11 & 4 & 0 & 0 & 0 & 0 & 0 \\
\hline 12 & 5 & 0 & 0 & $2(40)$ & 0.52 & $2(0.52)$ \\
\hline 13 & 23 & $1(4.35)$ & 0.26 & $14(60.9)$ & 3.65 & $15(3.91)$ \\
\hline 14 & 4 & 0 & 0 & $3(75)$ & 0.78 & $3(0.78)$ \\
\hline 15 & 5 & 0 & 0 & $3(60)$ & 0.78 & $3(0.78)$ \\
\hline 16 & 56 & $3(5.36)$ & 0.78 & $38(67.9)$ & 9.9 & $41(10.68)$ \\
\hline 17 & 29 & 0 & 0 & $18(62.1)$ & 4.69 & 18 (4.69) \\
\hline 18 & 27 & $2(7.4)$ & 0.52 & $16(59.25)$ & 4.17 & 18 (4.69) \\
\hline 19 & 27 & $1(3.7)$ & 0.26 & $13(48.15)$ & 3.39 & $14(3.65)$ \\
\hline 20 & 74 & $7(9.46)$ & 1.82 & $46(62.16)$ & 11.98 & $53(13.8)$ \\
\hline Total & 384 & 26 & 6.77 & 216 & 56.25 & $\begin{array}{l}242 \\
\quad(63.02)\end{array}$ \\
\hline
\end{tabular}

those reported by Tolosa et al. (2009) who reported the prevalence of $9.5 \%$ at Wolayta Sodo and Hundera et al. (2005) with the prevalence of $16.11 \%$ in and around Sebeta. In case of subclinical mastitis, the prevalence at cow level $(56.25 \%)$ in this study was comparable with the finding $54.4 \%$ reported by Biffa et al. (2005), 55.1\% by Zeryehun et al. (2013), and $55.8 \%$ by Bedada and Hiko (2011) but higher than $36.67 \%$ reported by Sori et al. (2005) and $44.16 \%$ by Biniam et al. (2015). The overall prevalence of subclinical mastitis at both cow and quarter level was found to be higher than clinical mastitis. This could be attributed to the little attention given to subclinical mastitis while treating clinical cases. According to Sori et al. (2005), subclinical mastitis was higher than clinical mastitis owing to the defense mechanism of the udder, which reduces the severity of the disease. Moreover, farmers in Ethiopia are not well informed about the silent cases of mastitis (Zeryehun et al. 2013).

The prevalence of mastitis was higher in older cows (29.69) than young adults (13.02\%) and adults $(20.31 \%)$. The increasing prevalence of mastitis with increasing age is in agreement with the findings by Dego and Tareke (2003) and by Abera et al. (2013) who found that the risk of mastitis increase significantly with the advancing age of the cow. Radostitis et al. (2007) have explained that older cows have largest teats and more relaxed sphincter muscles, which increase the accessibility of infectious agent in the cows' udder. The increase in prevalence of mastitis with parity reported in the study is comparable with the previous reports (Biffa et al. 2005; Tamirat 2007; Mekibib et al. 2010a, b; Moges et al. 2011; Biniam et al. 2015). This might be due to the increased opportunity of infection with time and the prolonged duration of infection, especially in a herd without mastitis control program and also an increase for teat injuries (Radostitis et al. 2007).

The study also showed that there were significant statistical association between prevalence of mastitis with herd size, floor types, and breeds. This finding is in agreement with Sori et al. (2005); Moges et al. (2011); Kassa et al. (2014). Quinn et al. (1999) have explained that genetic predisposition factors to mastitis such as teat shape, sphincter tone, anatomy of the teat canal, and susceptibility to weakening of the suspensory ligament ("pendulous udder"). In line with this, it was found in this study that the prevalence of mastitis in crossbred cows was statistically higher than that of local cattle.

From 446 milk samples subjected to bacteriological examinations, $10.3 \%(n=46)$ of $S$. agalactiae was isolated. This finding is comparable with the report of Zeryehun et al. (2013) and Yohannes and Molla (2013) which were 21.2 and $17.78 \%$ respectively and much higher than the report of $\mathrm{G} / \mathrm{Michael}$ et al. (2013) which was $1.6 \%$, but lower than $26.5 \%$ by Megersa et al. (2012). A high proportion of $S$. agalactiae 
$(17.36 \%)$ was isolated from CMT-positive cows. This could be because $S$. agalactiae is a highly contagious obligate parasite of the bovine mammary gland (Meiri-Bendek et al. 2002).

\section{Conclusion}

The study showed that the prevalence of mastitis at cow and quarter levels to be high which affects the dairy production. In this study, $S$. agalactiae was isolated more from subclinically infected cows. This indicates that contagious mastitis was prevailing in the studied farms and could be associated with unhygienic milking practice and poor herd management by the farms.

Acknowledgements The authors would like to thank the laboratory technicians at the Veterinary Microbiology laboratory for the realization of the research.

\section{Compliance with ethical standards}

Conflict of interest The authors declare that there is no conflict of interest.

Open Access This article is distributed under the terms of the Creative Commons Attribution 4.0 International License (http:// creativecommons.org/licenses/by/4.0/), which permits unrestricted use, distribution, and reproduction in any medium, provided you give appropriate credit to the original author(s) and the source, provide a link to the Creative Commons license, and indicate if changes were made.

Publisher's note Springer Nature remains neutral with regard to jurisdictional claims in published maps and institutional affiliations.

\section{References}

Abera, M., B. Demie, K. Aragaw, Regassa F., and Regassa, A. (2013). Isolation and identification of Staphylococcus aureus from bovine mastitic milk and their drug resistance patterns in Adama town, Ethiopia. J. Vet. Med. and Anim. Health, 1(2): 19-23.

Andersen, H.J., Pedersen, L.H, Aarestrup, F.M, Chriél, M. (2003). Evaluation of the surveillance program of Streptococcus agalactiae in Danish dairy herds. J. Dairy Sci. 86:1233-1239.

Andrews, A.H., Blowey, R.W., Boyd, H., Eddy, R.G. (2003). Bovine medicine: diseases and husbandry of cattle. Blackwell Publishing, Victoria, pp. 427-432.

Baker, CJ. (2000). Group B streptococcal infections. In: Stevens D. L, Kaplan E. L, editorseds. Streptococcal infections. Clinical aspects, microbiology, and molecular pathogenesis. New York: Oxford University Press. p. 222-37.

Bedada, B. A. and Hiko, A. (2011). Mastitis and antimicrobial susceptibility test at Asella, Oromia Regional state, Ethiopia. J. Microbiol.Antimicrobials. 3(9), 228-232 View at Google Scholar.

Biffa, D., Debela, E., Beyene, F. (2005). Prevalence and risk factor of mastitis in lactating dairy cows in southern Ethiopia, Int. J. Appl.Res. Vet. Med. 3(3):189-198.
Biniam, T., Rediet, T. and Yonus, A. (2015). Prevalence and potential risk factors of bovine mastitis in selected dairy farms of dire Dawa town, Eastern Ethiopia. Appl. J. hygiene, 4 (1): 06-11.

Bishi, A S. (1998). Cross-sectional and longitudinal prospective of bovine clinical and subclinical mastitis in the urban and periurban production sytems in Addis Ababa region, (Msc Thesis, Free university of Berlin, Germany and Addis Ababa University, Ethiopia, Joint Programme).

Christos, M. (2011). Study on prevalence and risk factors of bovine mastitis in and around Mekelle small scale dairy farm. DVM Thesis. Mekelle University, Mekelle, Ethipia.

Dego, O. K., and Tareke, F. (2003). Bovine mastitis in selected areas of southern Ethiopia. Trop. Anim. Health Prod., 197-205.

Erskine, R.J. (1992). Mastitis control in dairy herds with high prevalence of subclinical mastitis. Compend Contin Educ PractVet. 14:969-979.

G/Michael, L., Deressa, B., Begn, F., Mekuria, A. (2013). Study on prevalence of bovine mastitis in lactating cows and associated risk factors in and around Areka town, Southern of Ethiopia. Afr. J. Microbiol. Res. 7(43), pp. 5051-5056.

Hundera, S., Ademe, Z, Sintayehu, A. (2005). Dairy cattle mastitis in and around Sebeta, Ethiopia. Intern. J. Appl. Vet. Med. 3(4): 1525-1530.

Kassa, F., Ayano, A.A., Abera, M., kiros, A. (2014). Longitudinal study of bovine mastitis in Hawassa and Wendo Genet Small Holder Dairy Farms Global J. Sci. Frontier Res. 14 (2): 33-41.

Megersa, B., Manedo, A., Abera, M., Regassa, A. and Abunna, F. (2012). Mastitis in lactating cows at Hawassa town: prevalence, risk factors, major bacterial causes and treatment response to routinely used antibiotics. American. J. Sci. Res. 7(2): 86-91.

Meiri-Bendek, I., E. Lipkin, A. Friedmann, G. Leitner,, A. Saran, S. Friedman and Kashi, Y. (2002). A PCR-based method for the detection of Streptococcus agalactiae in Milk. J. Dairy Sci. 85:17171723.

Mekibib, B., Fergasa, M., Abunna, F., Megersa, B., Regassa, A. (2010a). Bovine mastitis: prevalance, risk factors and major pathogens in dairy farms of Holeta town, Central Ethiopia. Vet. World. 3:397403.

Moges, N, Asfaw, Y. and Belihu, K. (2011). A cross sectional study on the prevalence of subclinical mastitis and associated risk factors in and around Gondar, Northern Ethiopia. Int. J. Ani. Vet. Adv. 3(6): 455459.

Mungube, E.O, Tenhagen B. A, Regassa F, Kuyle M. N, Sheferaw Y, Kassa T, Baumann MPO. (2005). Reduced milk production in udder quarters with subclinical mastitis and associated economic losses in crossed breed dairy cows in Ethiopia. Trop. Anim. Health. Prod. 37(6):503-512.

Mungube, E. O., Tehagen, B. A., Kassa, T., Regassa, F., Kyule, M. N., Greiner, M. and Baumann, M. P. O. (2004). Risk factors for dairy cow mastitis in the central highlands of Ethiopia. Tropical Animal Health and Production, 36:463-472.

Mureda, E. and Mekuria, Z. (2008). Reproductive performance of crossbreed dairy cows in eastern lowlands of Ethiopia. LSRD, 20(4): 0121-3778.

Quinn, P.J. Carter, M.E. Markey, B. and Carter, G.R. (1999). Clinical veterinary microbiology, Mosby: London. pp. 21-66.

Quinn, P. J. Carter, M.E., Markey, B. K. and Carter, G. R. (2002). Veterinary microbiology microbial diseases, bacterial causes of bovine mastitis, 8th Edition, Mosby International Limited, London, pp 465-475.

Radostitis, O. M., Gay, C. C., Hinchcliff, K. W. and Constable, P. D. (2007). Mastitis. In: Veterinary medicine: a text book of disease of cattle, sheep, pigs, goats, and horses 10th edition, Ballier, Tindall, London. Pp 674-762.

Sandy, C. (2011). Milk Quality Pays:Streptococcus agalactiae (Strep ag) Mastitis. A review can.vet J. pp. 1-5. 
Shimelis, A., (2010). Prevalence of abomasal nematode in small ruminants slaughtered at Haramaya Municipal Abattoir, Eastern Hararghe, Ethiopia.

Sori, H., Zerihun, A. and Abdicho, S. (2005). Dairy cattle mastitis in and around Sebeta. Intern J Appl Res Vet Med. 3: 338-341.

Tamirat, T.A. (2007). Comparison of clinical trials of bovine mastitis with the use of honey, MSc thesis, Addis Ababa University, Ethiopia. pp. 14-30.

Thursfield, M. 2005. Veterinary Epidemiology. 3rd. Blackwell science, Ltd., London, UK. 228-246.

Tolla, T. (1996). Bovine mastitis in indigenous zebu and Borona Holistein crosses in Southern Wollo. Addis Ababa University, Faculty of Veterinary Medicine, Debre Zeit, Ethiopia.

Tolosa T, Geberetsadik Z, Regassa F. (2009). Bovine mastitis and its associated risk factor in lactating cow in Wolayta Sodo, Southern Ethiopia, Animal Health Production. 57(4):311-319

Yohannes, M. and Molla, W. (2013). Prevalence, risk factors and major bacterial causes of bovine mastitis in and around Wolaita Sodo, Southern Ethiopia. Global J. Microbiol Res. 1(1), Pp 106-111.

Zeryehun T, Aya, T. and Bayecha, R. (2013). Study on prevalence, bacterial pathogens and associated risk factors of bovine mastitis in small holder dairy farms in and around Addis Ababa, Ethiopia. The J. Anim \& Plant Sci., 23(1): Pp: 50-55View at Google Scholar $\cdot$ View at Scopus.
A. Kifle and T. Tadele, Prevalence of sub clinical mastitis in small holder dairy farms in Selale, North Shewa Zone, Central Ethiopia, The Internet Journal of Veterinary Medicine, vol. 5, no. 1, pp. 1-4, 2008. View at Publisher View at Google Scholar

G. Almaw, W. Molla, and A. Melaku, Prevalence of bovine subclinical mastitis in Gondar town and surrounding areas, Ethiopia. Livestock Research for Rural Development, vol. 21, 7, 2009. View at Google Scholar View at Scopus

B. Mekibib, M. Furgasa, F. Abunna, B. Megersa, and A. Regassa, Bovine mastitis: prevalence, risk factors and major pathogens in dairy farms of holeta town central Ethiopia Veterinary World, vol. 3, no. 9, pp. 397-403, 2010b. View at Publisher · View at Google Scholar · View at Scopus

T. Sori, J. Hussien, and M. Bitew, Prevalence and susceptibility assay of Staphylococcus aureus isolated from bovine mastitis in dairy farms of Jimma town, South West Ethiopia, Journal of Animal and Veterinary Advances, vol. 10, no. 6, pp. 745-749, 2011. View at Publisher · View at Google Scholar · View at Scopus

H. Dabash, A. Petros, and A. Fekadu, Prevalence and identification of bacterial pathogens causing bovine mastitis from crossbred of dairy cows in North Showa Zone of Ethiopia, Global Veterinaria, vol. 13, no. 2, pp. 189-195, 2014. View at Google Scholar 